\title{
DESIGN OF A WIDEBAND PLANAR ANTENNA ON AN EPOXY-RESIN-REINFORCED WOVEN-GLASS MATERIAL
}

\section{ŠIROKOPASOVNA PLOSKOVNA ANTENA NA EPOKSI SMOLI, OJAČANI S STEKLENIMI VLAKNI}

\author{
Rezaul Azim¹, Mohammad Tariqul Islam² \\ ${ }^{1}$ University of Chittagong, Chittagong 4331, Bangladesh \\ ${ }^{2}$ Department of Electrical, Electronic \& Systems Engineering, Universiti Kebangsaan Malaysia, 43600 UKM Bangi, Malaysia \\ razim71@gmail.com
}

Prejem rokopisa - received: 2013-09-30; sprejem za objavo - accepted for publication: 2014-03-28

doi:10.17222/mit.2013.169

\begin{abstract}
In this study, the design and prototyping of a compact planar antenna is presented for wideband applications. The designed transmission-line-fed antenna is composed of a rectangular radiating patch and a partial ground plane and is printed on both sides of a $1.6 \mathrm{~mm}$ thick, epoxy-resin-reinforced, woven-glass dielectric material. The antenna structure is planar, and its design is simple and easy to fabricate. Compared to the other substrate materials, the proposed antenna on epoxy-resin, woven-glass material could achieve a wider and less-expansive bandwidth. Experimental results show that the designed antenna could achieve an impedance bandwidth (return loss $\geq-10 \mathrm{~dB}$ ) from $2.99 \mathrm{GHz}$ to $18.31 \mathrm{GHz}(6.12: 144.33 \%)$. Moreover, the antenna has a good gain and exhibits stable radiation patterns within the operating band. Details of the proposed antenna are presented and discussed.

Keywords: wideband, microstrip patch, planar antenna, epoxy resin, fiberglass
\end{abstract}

$\mathrm{V}$ tej študiji je predstavljena zgradba in izdelava kompaktne ploskovne antene za širokopasovno uporabo. Zasnovana oddajno-sprejemna antena je sestavljena iz pravokotne sevalne in delno ozemljitvene ploskve ter natisnjena na obeh straneh 1,6 mm velike ploščice iz epoksidne smole, ojačane z dielektričnimi steklenimi vlakni. Antena je ploskovna, enostavne zgradbe in enostavna za izdelavo. V primerjavi z drugimi materiali podlage predlagana zasnova na epoksidni smoli s tkanino iz steklenih vlaken omogoča večjo pasovno širino in manjšo ekspanzivnost. Eksperimentalni rezultati kažejo, da predlagana antena lahko doseže impedančno pasovno širino (povratna izguba $\geq-10 \mathrm{~dB}$ ) od 2,99 GHz do $18,31 \mathrm{GHz}(6,12: 144,33 \%)$. Poleg tega ima antena dober izkoristek in kaže stabilne vzorce sevanja v delovnem pasu. Predstavljene in obravnavane so podrobnosti o predloženem oblikovanju antene.

Ključne besede: širokopasovni, mikrotrakasta ploskev, ploskovna antena, epoksidna smola, steklena vlakna

\section{INTRODUCTION}

In wireless communications technology the necessity for wide and multi-band antennas is increasing rapidly due to the need to support more users and to provide information with higher data-transmission rates. Microstrip antennas are one the most suitable structures due their low profile and ease of fabrication. Compared to conventional, three-dimensional types of antennas, planar microstrip antennas printed on a piece of printed-circuit board have become very popular in modern wireless communications because they can be easily embedded into wireless devices or integrated with other RF circuitry. Usually, a planar design can be used to reduce the volumetric size of a wideband antenna by replacing the three-dimensional radiating elements with their planar versions. ${ }^{1-3}$

Different types of planar antennas have already been proposed for wideband applications. A variety of dielectric materials have been used for the design and prototyping of these antennas. A dielectric material used for the design of wideband antennas is required to feature a higher permittivity and lower dissipation factor. ${ }^{4}$ Materials with a lower permittivity are good insulators for lower-frequency signals requiring high isolation in densely packed circuits, such as mobile communications. ${ }^{5}$ On the other hand, materials with a higher dielectric constant have a greater capability to store charge and produce larger electromagnetic fields, but limited isolation between the conductors. ${ }^{6}$ Moreover, by using a material with a higher permittivity a compact antenna can be designed that is capable of achieving a very wide operating band. ${ }^{7}$ For example, in ${ }^{8}$ a miniaturized, modified, circular patch antenna was designed on a ceramicpolytetrafluroethylene (PTFE) composite material. With an overall size of $0.22 \lambda \times 0.29 \lambda \times 0.03 \lambda$, the proposed antenna achieved multi-band characteristics. However, the antenna failed to fulfill the requirement for a wideband antenna having triple operating bands of 5-6.3 $\mathrm{GHz}, 9.1-9.6 \mathrm{GHz}$ and $10.7-11 \mathrm{GHz}$. $\mathrm{In}^{9}$, a wideband, pentagon-shaped, planar microstrip slot antenna was designed on an epoxy-resin composite material. Combining the pentagon-shaped slot, feed line, and pentagon stub, the antenna obtained an impedance bandwidth of $124 \%$. However, its use in portable communication devices was limited due to its large ground plane. Ullah et al. ${ }^{10}$ proposed a double L-shaped multi-band patch antenna on a polymer-resin substrate 
material. By introducing two L-shaped slots in the rectangular patch, the designed antenna could achieve a dual operating band centered at $4.85 \mathrm{GHz}$ and $8.1 \mathrm{GHz}$, and thus not suitable for broadband wireless communications.

In this study, a simple planar monopole antenna that achieves a physically compact planar profile having sufficient impedance bandwidth and a stable radiation pattern is proposed for wideband applications. The antenna consists of a rectangular radiating patch and a partial ground plane. The transmission line-fed radiating patch is printed on one side of an epoxy-matrix-reinforced, woven-glass material, while the partial ground plane is printed on the other side. The epoxy-matrixreinforced, woven-glass material is a popular and versatile high-pressure thermo set plastic laminate grade with a low dissipation factor; it is the most commonly used electrical insulator that possesses a good mechanical strength and a nearly zero water-absorption coefficient. It is observed that the radiating patch of the proposed design has a strong coupling with the ground plane and the antenna, designed on polymer-resin composite material, is capable of supporting multiple resonance modes. The overlapping of these multiple resonance modes leads to the characterization of a wideband ranging from $2.99 \mathrm{GHz}$ to $18.31 \mathrm{GHz}$. The simple structure, ease of fabrication, low cost, wide operating band and stable radiation patterns make the proposed antenna suitable for use in WiMAX, WLAN, C-band, UWB and X-band applications.

\section{ANTENNA DESIGN}

The design layout of the proposed wideband antenna is illustrated in Figure 1. The antenna is designed and analysed using the method of the moment based, fullwave electromagnetic field solver IE3D. The antenna is printed on both sides of a $1.6 \mathrm{~mm}$ thick double-layer dielectric substrate. The dielectric material consists of an epoxy-matrix-reinforced woven glass. The fiberglass in the composition is $60 \%$, while the epoxy resin contributes $40 \%$ of the composition. This composition of epoxy resin and fiberglass varies in the thickness and is direction dependent. One of the attractive characteristics of polymer-resin composites is that they can be shaped and reshaped repeatedly without losing their material characteristics. ${ }^{11}$ Due to the ease of fabrication, design flexibility, low manufacturing costs and market availability, the epoxy-matrix-reinforced, woven-glass material has become popular in the design of communication devices.

A microstrip transmission line fed rectangular patch of $13.5 \mathrm{~mm} \times 14.5 \mathrm{~mm}$ is printed on one side of the dielectric material, while the partial ground plane with a side length of $5.5 \mathrm{~mm}$ is printed on the opposite side. The value of the width and length of the transmission line is set at $2.75 \mathrm{~mm}$ and $6 \mathrm{~mm}$, respectively, so that the input impedance of the feeding of the antenna becomes equivalent to $50 \Omega$. A copper cladding $35 \mu \mathrm{m}$ is used to

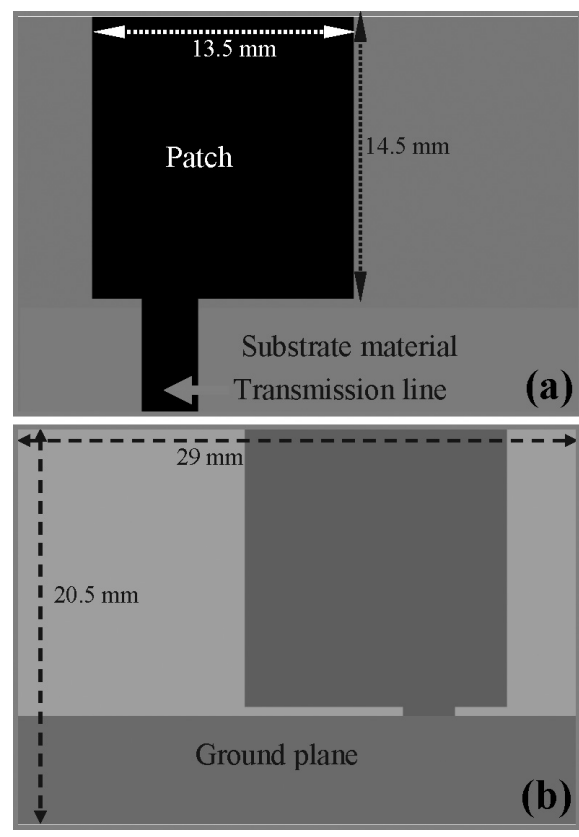

Figure 1: a) Top and b) bottom views of the proposed design Slika 1: Videz predlagane zgradbe: a) zgoraj in b) spodaj

metalise the patch, feed line and the ground plane of the proposed antenna. The overall dimension of the designed wideband antenna is optimized to a compact size of 29 $\mathrm{mm} \times 20.5 \mathrm{~mm}$, which is much smaller than the antennas proposed in $^{9,12-14}$ and very suitable to be integrated into portable communication devices.

To investigate the effect of different dielectric materials on the performance of the proposed antenna, a parametric study was conducted. The properties of the dielectric materials are tabulated in Table 1, while their effect on the return-loss characteristics is depicted in Figure 2. It is clear from the plot that the proposed antenna with an epoxy-matrix-reinforced, woven-glass material exhibits a wider operating band than the glass and ceramic PTFE. Although the antenna with the ceramic PTFE composite material achieved a lower operating frequency because of the high dielectric constant, its bandwidth is narrower compared to glass PTFE and epoxy resin and is extremely expensive compared to the epoxy-resin dielectric material.

Table 1: Properties of the dielectric materials

Tabela 1: Lastnosti izolacijskih materialov

\begin{tabular}{|c|c|c|}
\hline Dielectric material & Permittivity & Loss tangent \\
\hline Glass PTFE & 2.2 & 0.0009 \\
\hline Ceramic PTFE & 10.2 & 0.002 \\
\hline Epoxy resin & 4.6 & 0.02 \\
\hline
\end{tabular}

The return-loss characteristics in Figure 2 show that the proposed antenna with epoxy resin material exhibits six resonances across the operating band, of which the first appears at $3.4 \mathrm{GHz}$, the second at about $6.45 \mathrm{GHz}$, the third at $9.7 \mathrm{GHz}$, the fourth at $11.0 \mathrm{GHz}$, the fifth at $12.75 \mathrm{GHz}$ and the final resonance is at $16.17 \mathrm{GHz}$. The figure clearly indicates that the overlapping of these 


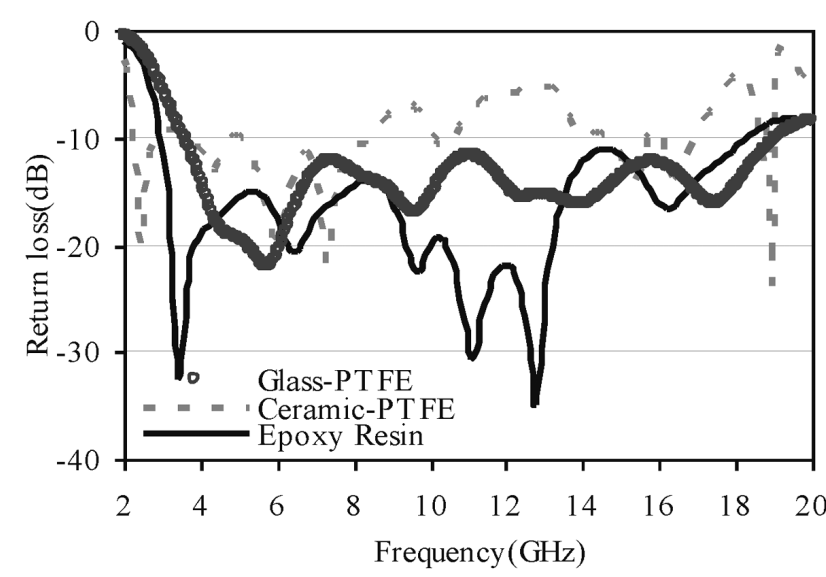

Figure 2: Return-loss characteristics for different materials Slika 2: Značilnosti povratnih izgub za različne materiale

resonances that are closely spaced across the spectrum leads to a wide operating bandwidth, ranging from 2.96 $\mathrm{GHz}$ to $18.31 \mathrm{GHz}$. At the first resonance frequency, when the antenna size is smaller than the corresponding wavelength, the electromagnetic signal can couple to the antenna size and can operate in the stationary wave mode. As the frequency increases, the antenna starts to operate in the mixed stationary wave and the travelling wave modes. At the higher edge frequency of the operating band, the antenna size becomes larger, corresponding to the respective wavelength, and the electromagnetic signals have to travel a long distance, resulting in a dominating travelling wave mode, as shown in Figure 3, which depicts the input impedance of the proposed antenna.

\section{RESULTS AND DISCUSSION}

The return-loss characteristic of the realised antenna was measured in an anechoic chamber using an Agilent E8362C vector network analyser. Figure 4 plots the measured and simulated return-loss curves. The simulated $-10 \mathrm{~dB}$ return-loss bandwidth ranges from 2.96 $\mathrm{GHz}$ to $18.31 \mathrm{GHz}$, equivalent to a fractional bandwidth

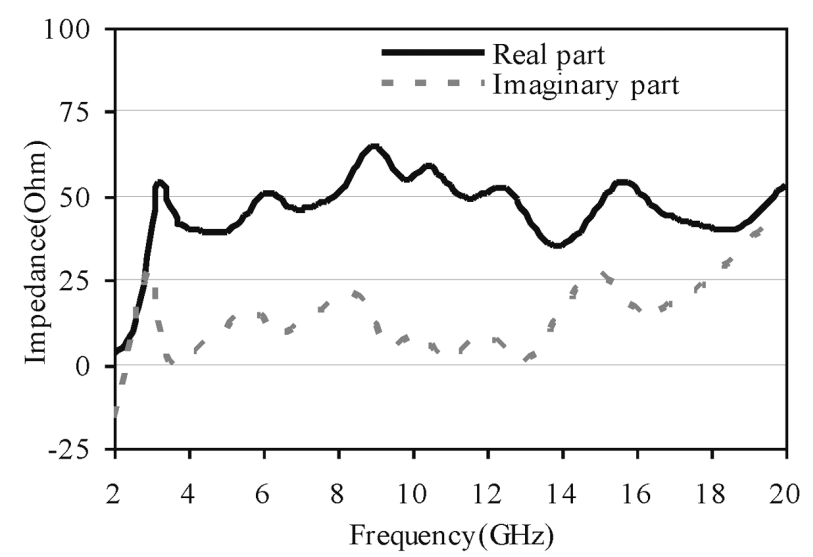

Figure 3: Real and imaginary parts of the input impedance Slika 3: Realni in navidezni del vhodne impedance

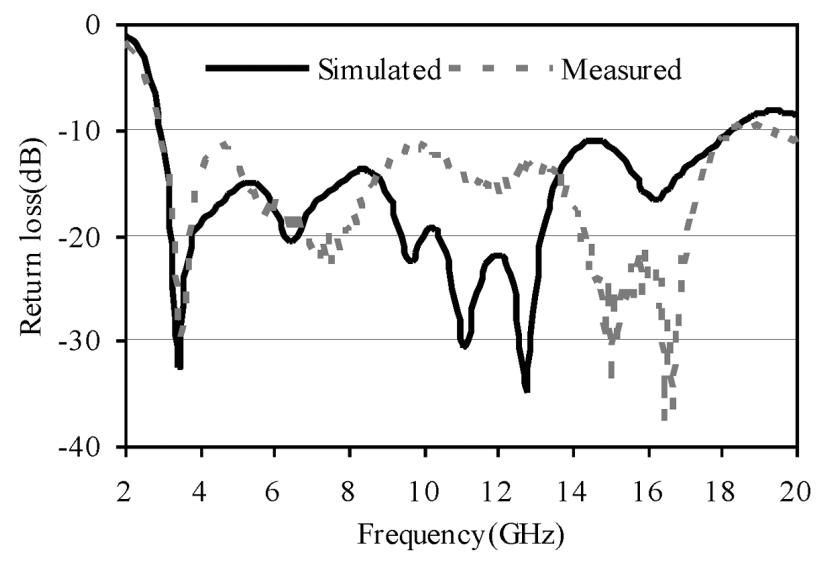

Figure 4: Measured and simulated return losses

Slika 4: Izmerjene in simulirane povratne izgube

of $144.33 \%$. This wideband characteristic of the proposed planar antenna is confirmed in measurements, with only a small shift of the lower edge frequency to $2.99 \mathrm{GHz}$. Despite a very small size, the proposed antenna achieved a sufficient operating band to cover the WiMAX, WLAN, C-band, UWB and X-frequency bands.

Although there is a disparity between the measured and simulated resonances that can possibly be attributed to the manufacturing tolerances and imperfect soldering effects of the SMA connector, the measured resonance frequencies are nearly identical to the simulated frequency. This mismatch may also be due to the effect of the RF feeding cable, which is used in the measurements, but not considered during the simulation. The ripples observed in the measured result may be caused by the current drain from the conducting ground plane to the outer shield of the RF feeding cable, which is not presumed during the simulation.

The peak gain of an epoxy-resin-based, wide-band antenna is illustrated in Figure 5. Despite a very compact dimension, the designed antenna exhibits a good gain. As the antenna would be used for short-distance wireless communication, the achieved peak gain is within the acceptable limits. The gain of the proposed

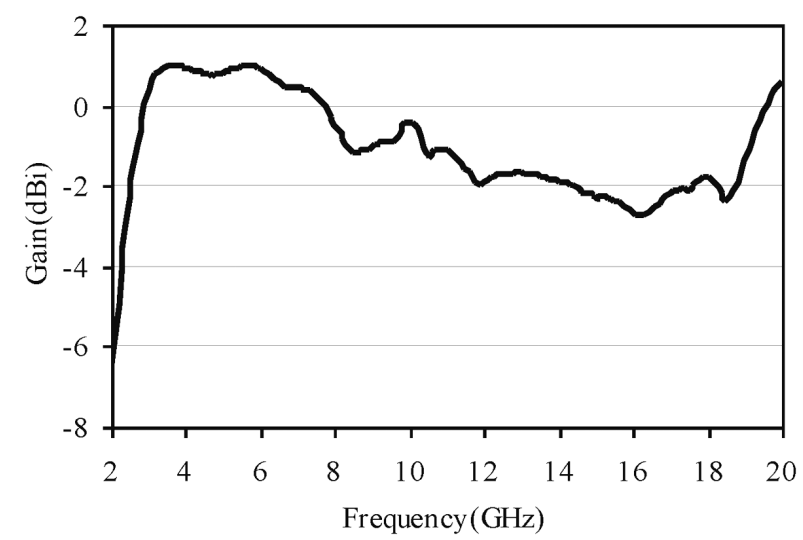

Figure 5: Gain of the proposed wideband antenna Slika 5: Izkoristek predlagane širokopasovne antene 

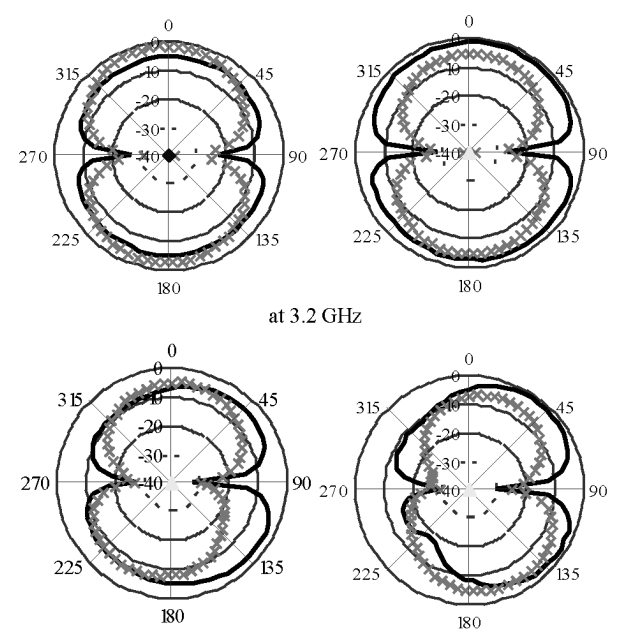

at $6.1 \mathrm{GHz}$

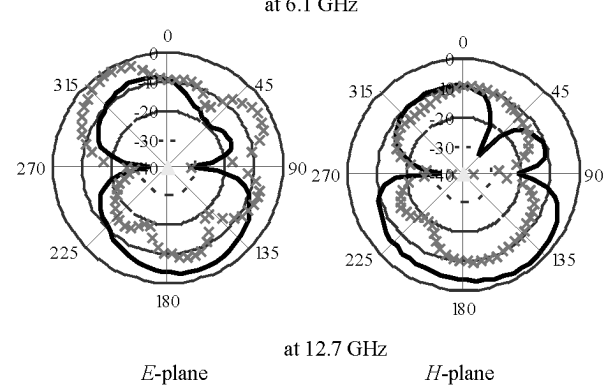

Figure 6: Radiation patterns at different frequencies (Solid line: co-polarised field, crossed line: cross-polarised field)

Slika 6: Vzorci sevanja pri različnih frekvencah (polna črta: kopolarizirano polje, prečno: prečno polarizirano polje)

antenna could be improved using ceramic PTFE microwave substrate material rather than epoxy-resin material. However, the use of the ceramic PTFE increases the cost of the antenna and hence this option is not considered in the design.

The $E$ - and $H$-plane radiation patterns of the proposed antenna at $(3.2,6.1$ and 12.7) $\mathrm{GHz}$ are depicted in Figure 6. At lower frequencies, the antenna exhibits a bidirectional radiation pattern for both the $E$ and $H$ planes, and the patterns are approximately the same as the pattern of a typical monopole antenna. As the frequency increases, a higher-order harmonic is introduced to the patterns, and both the $H$ and $E$ planes become more directional, but still retain their bidirectionality. Some dips are observed, mainly at higher frequencies, and might be because the microstrip feed line is printed directly below the partial ground plane and might also be caused by the feed connector. However, the radiation patterns are remarkably stable throughout the operating band.

\section{CONCLUSIONS}

A compact planar microstrip antenna is designed and fabricated for a wideband application. The proposed antenna consists of a partial ground plane and a transmission-line-fed rectangular radiating element. The antenna design is analysed and optimised by the method of moment-based software IE3D and is verified by means of a prototype. The antenna is designed and fabricated on epoxy-matrix-reinforced, woven-glass material. Compared to the other dielectric materials, the proposed antenna with an epoxy matrix reinforced woven-glass material exhibits better performance in terms of bandwidth, return-loss, gain and radiation patterns. Experimental results show that the proposed antenna could achieve an impedance bandwidth from $2.99 \mathrm{GHz}$ to 18.31 GHz $(6.12: 1,15.32 \mathrm{GHz})$ for a return loss of $\geq-10 \mathrm{~dB}$. Moreover, the antenna achieved a good gain and stable radiation patterns. All these features of the proposed epoxy-resin-based antenna make it a worthy candidate for wideband applications in portable communication devices.

\section{REFERENCES}

${ }^{1}$ M. J. Ammann, Z. N. Chen, Wideband monopole antennas for multiband wireless systems, IEEE Antennas and Propagation Magazine, 45 (2003), 146-150, doi:10.1109/MAP.2003.1203133

${ }^{2}$ X. H. Wu, Z. N. Chen, Comparison of planar dipoles in UWB applications, IEEE Transactions on Antennas and Propagations, 53 (2005), 1973-1983, doi:10.1109/TAP.2005.848471

${ }^{3}$ M. Samsuzzaman, M. T. Islam, J. S. Mandeep, N. Misran, Printed wide-slot antenna design with bandwidth and gain enhancement on low-cost substrate, The Scientific World Journal 2014 (2014), Article ID 804068, 10 pages, doi:10.1155/2014/804068

${ }^{4} \mathrm{~K}$. Oohira, Development of an antenna material based on rubber that has flexibility and high impact resistance, NTN Technical Review, 76 (2008), 58-63

${ }^{5}$ M. Samsuzzaman, M. T. Islam, J. S. Mandeep, Parametric analysis of a glass-micro fibre-reinforced PTFE material, multiband, patchstructure antenna for satellite applications, Optoelectronics and Advanced Materials-Rapid Communications, 7 (2013), 760-769

${ }^{6}$ A. Aguayo, Analyzing advances in antenna materials, Antenna Systems \& Technology, 12 (2010), 14-15

${ }^{7}$ M. H. Ullah, M. T. Islam, A compact square loop patch antenna on high dielectric ceramic-PTFE composite material, Applied Physics A, 113 (2013), 185-193, doi:10.1007/s00339-012-7511-4

${ }^{8}$ M. H. Ullah, M. T. Islam, Miniaturized modified circular patch monopole antenna on ceramic-polytetrafluroethylene composite material substrate, Journal of Computational Electronics, 13 (2014), 211-216, doi:10.1007/s10825-013-0501-8

${ }^{9}$ S. K. Rajgopal, S. K. Sharma, Investigations on ultrawideband pentagon shape microstrip slot antenna for wireless communications, IEEE Transactions on Antennas and Propagations, 57 (2009), 1353-1359, doi:10.1109/TAP.2009.2016694

${ }^{10}$ M. H. Ullah, M. T. Islam, J. S. Mandeep, N. Misran, A new double L-shape multiband patch antenna on polymer resin material substrate, Applied Physics A: Materials Science \& Processing, 110 (2012), 199-205, doi:10.1007/s00339-012-7114-0

${ }^{11}$ I. Yarovskya, E. Evansb, Computer simulation of structure and properties of crosslinked polymers: application to epoxy resins, Polymer, 43 (2002), 963-969, doi:10.1016/S0032-3861(01)00634-6

${ }^{12}$ R. Azim, M. T. Islam, N. Misran, Microstrip line-fed printed planar monopole antenna for UWB applications, Arab Journal for Science and Engineering, 38 (2013), 2415-2422, doi:10.1007/s13369-0130553-X

${ }^{13}$ L. Liu, S. W. Cheung, R. Azim, M. T. Islam, A compact circular-ring antenna for ultra-wideband applications, Microwave and Optical Technology Letters, 53 (2011), 2283-2288, doi:10.1002/mop

${ }^{14}$ R. Azim, M. T. Islam, N. Misran, A. T. Mobashsher, Compact UWB planar antenna for broadband applications, Informacije MIDEM, 41 (2011), 37-40 